\title{
Shared learning in an interconnected world: innovations to advance global health equity
}

\author{
Agnes Binagwaho $1,2,3^{*}$, Cameron T Nutt ${ }^{4}$, Vincent Mutabazi ${ }^{5}$, Corine Karema ${ }^{5}$, Sabin Nsanzimana ${ }^{5}$, Michel Gasana ${ }^{5}$, \\ Peter C Drobac ${ }^{2,6,7}$, Michael L Rich ${ }^{2,6,7}$, Parfait Uwaliraye ${ }^{1}$, Jean Pierre Nyemazi ${ }^{5}$, Michael R Murphy ${ }^{8}$, \\ Claire M Wagner ${ }^{9}$, Andrew Makaka ${ }^{1}$, Hinda Ruton ${ }^{1}$, Gita N Mody ${ }^{7}$, Danielle R Zurovcik ${ }^{10}$, Jonathan A Niconchuk ${ }^{2,6}$, \\ Cathy Mugeni ${ }^{1}$, Fidele Ngabo ${ }^{1}$, Jean de Dieu Ngirabega ${ }^{5}$, Anita Asiimwe ${ }^{1}$ and Paul E Farmer ${ }^{2,6,7}$
}

\begin{abstract}
The notion of "reverse innovation"-that some insights from low-income countries might offer transferable lessons for wealthier contexts--is increasingly common in the global health and business strategy literature. Yet the perspectives of researchers and policymakers in settings where these innovations are developed have been largely absent from the discussion to date. In this Commentary, we present examples of programmatic, technological, and research-based innovations from Rwanda, and offer reflections on how the global health community might leverage innovative partnerships for shared learning and improved health outcomes in all countries.
\end{abstract}

\section{Introduction}

In the early 2000s, citizens across Africa were mobilizing for access to the lifesaving antiretroviral therapy (ART) that had led to dramatic declines in AIDS mortality in the United States and Europe. Though the AIDS pandemic was crippling economies across the continent and countries faced the real prospect of losing an entire generation, many in public health placed effective treatment in opposition to prevention. Leading medical journals published modeling studies with confident assertions that flatly stated, for example, that "prevention is at least 28 times more cost-effective than ART [in Africa]" [1]; at least one influential voice in development circles argued that Africans living with HIV could never adhere to therapy because they "don't know what Western time is [2]." These assertions, though un-buttressed by data, were typical of attitudes widespread among opinion makers in public health and within institutions charged with promoting health and economic development.

A decade later, in the wake of unprecedented international solidarity and funding, more than 7.1 million women, men, and children are receiving ART in Africa

\footnotetext{
* Correspondence: agnes_binagwaho@hms.harvard.edu

1 Ministry of Health of Rwanda, Kigali, Rwanda

${ }^{2}$ Harvard Medical School, Boston, MA, USA

Full list of author information is available at the end of the article
}

[3]. New studies have shown ART to reduce the likelihood of HIV transmission by up to 96\% [4], and pooled analyses have demonstrated that African patients exhibit significantly higher adherence to treatment than their North American counterparts [5]. In Rwanda, AIDS-related deaths have declined by $83.1 \%$ since 2000 - even more steeply than the comparable post-ART period after 1996 in Europe and North America [6]. An estimated 83.3\% percent of HIVpositive adults on ART in Rwanda are virally suppressed [7], and community-based approaches to HIV care delivery refined in Rwanda and Haiti are now being implemented in the United States [8].

Pathologies from AIDS to cancer do not discriminate along lines of nationality, yet the notion that poor countries' experiences addressing such conditions might offer lessons for settings rich and poor alike has only recently been recognized in the medical literature [9-12]. Most discussion to date has termed such exchanges "reverse innovation," [8] though some have argued for a more explicitly bi-directional framework that recognizes best practices regardless of where they emerge [13-15].

\section{Towards a learning health system}

While numerous gaps still exist (especially with regards to human resources), Rwanda has made significant progress in recent years towards an enabling regulatory and academic environment for evidence-based health

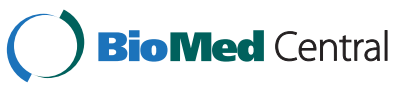


innovation [16]. Most recently, the Rwandan government adopted a national Health Sector Research Policy to guide work from clinical trials to operational and social science research [17]. Research based on local needs has been an engine of improvement in the health sector, and has contributed to Rwanda's likely achievement of the health-related Millennium Development goals $[18,19]$.

We contend that Rwanda's linkage of equitable health care delivery to research has catalyzed health innovation through three specific mechanisms. First, major health financing and care delivery initiatives have been evaluated through carefully planned phased-rollouts and investigational designs that students of innovation call "disciplined experiments" [20] (Table 1). Such approaches can be challenging to plan and controversial when they inevitably threaten conventional ways of doing things, but they are invaluable for learning and improving.

A second and more routine approach to studying and disseminating innovations has been individual policymakers' commitment to (and their institutions' support for) retrospectively evaluating novel strategies to improve service delivery. Countries across Africa-and the world-face many of the same challenges, from treatment of multidrugresistant tuberculosis patients co-infected with HIV to delivery of three doses of the human papillomavirus vaccine to adolescent girls. The innovations require rigorous monitoring and evaluation to objectively report their effect on the health system. Publication of Rwanda's experiences in international peer-reviewed journals has shared solutions that worked in Rwanda with researchers across continents and contexts, and has sparked a nascent culture of innovation and reflection in the health sector (Table 2).

Finally, Rwanda has sought to provide a supportive environment for the development of new health tools designed specifically for the rural African context (Table 3). When distributed equitably, new technologies can accelerate health gains and narrow inequalities [15]. Public sector authorities encourage local manufacturing of devices developed or studied in Rwanda, and the World Bank recently ranked Rwanda $8^{\text {th }}$ of 185 countries for ease of starting a business and the $2^{\text {nd }}$ most improved business reformer since 2005 [40]. Although much work remains to

\section{Table 1 "Disciplined experiments" to learn from,} improve, and scale innovations in care delivery

- $\quad$ Community-based health insurance scale-up [21,22]
- $\quad$ Performance-based financing for maternal and child health
- 23$]$ and HIV care delivery $[24]$
workers $[25,26]$
Comprehensive quality improvement and integrated platforms of
community-based district health services [27]

fabricate the majority of medical innovations in-country, the breadth of available processes and increasing attention to international quality standards are promising.

\section{Mutual capacity building}

New technologies and better ways of organizing services will matter little to patients, however, if there is no one to deliver them. As a result of the 1994 genocide, Rwanda faces one of the world's most severe human resources for health shortages. International partnerships, whether with non-governmental organizations or universities, are mandated to prioritize the transfer of capacity; over the past decade, however, it has become increasingly clear that the flow of knowledge goes-and, we argue, must go-the other way, too.

As one example, eight years of collaboration between the Rwandan Ministry of Health, the non-governmental organization Partners In Health, Harvard Medical School, and the Brigham and Women's Hospital in Boston has contributed to the launch of a new discipline of global health delivery [46]. With courses now taught in both Boston and rural Rwanda, and with masters-level programs launching in both settings, stakeholders in both nations have built capacity among students, clinicians, and faculty while accelerating pedagogical innovation [47]. Rwanda's Butaro District Hospital, built through a governmental partnership with MASS Design Group, Partners In Health, and the Clinton Health Access Initiative, is the site of design and infection control innovations that are being studied by architects as a model for contextually responsive, impact-oriented design, which could inform the way facilities are built to meet real needs globally, in both poor and wealthy nations $[48,49]$.

On a much larger scale, Rwanda launched its Human Resources for Health Program in 2012, partnering with 16 American academic medical centers to increase the quantity and skill level of Rwanda's physicians, nurses, midwives, and health managers, while diversifying the health workforce's skill mix over seven years [50]. Each participating American faculty member is contracted for a twelve-month period and "twinned" with a Rwandan counterpart; the resulting individual and institutional partnerships will bear fruit well beyond the program's end by creating cycles of innovation and learning in both directions. Most importantly, clinical practice and health systems are being enhanced in transformative ways in some of Rwanda's most remote districts [51].

\section{The future of innovation in global health}

As we have previously observed, for too long the world waited as "pathogens like HIV jet[ted] around the world" while "their remedies remain[ed] stuck in customs [52]." For many individual diseases, this situation is changing rapidly for the better; yet the global trade in ideas and 
Table 2 Rigorous monitoring and evaluation of health systems innovations

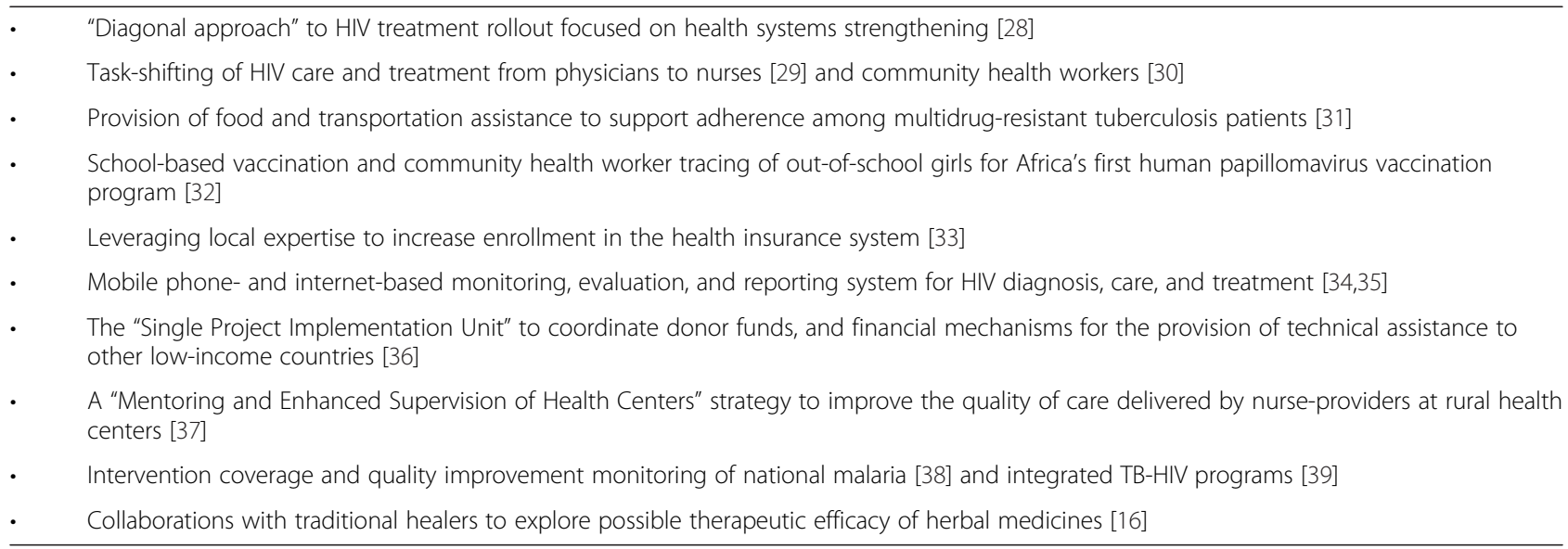

innovations in health care delivery remains stunted. Leading editors of and contributors to the global scientific commons are well positioned to disrupt the status quo and foster new channels of South-North and South-South communication through the medical literature, where the perspectives of researchers and policymakers from low-income settings are currently few and far between.

We therefore eagerly welcome Globalization and Health's new series on innovation in global health systems as an encouraging start [12]. But what might it take to catalyze a truly equal dialogue aimed at shared learning across borders and across historical gradients of inequality? Based on our experiences working together in Rwanda's health sector, we suggest five key ingredients below:

1. How will it benefit the poorest?-This fundamental question should be at the heart of all global health partnerships, whether for research, policy, or service delivery, and it should fuel conversations between implementing partners, funding institutions, IRBs, and policymakers.

2. Asking questions that matter to patients-Global health research agendas should be derived in part from patients' notions of what is most at stake-this means listening [53]. The provision of transportation fare support for HIV patients, for instance, might seem outside the realm of a traditional research partnership. Yet given the average family income in rural Africa, a monthly round-trip bus ticket to a far-away clinic poses a similar proportional financial burden as would a business-class airplane ticket from Boston to Los Angeles for a middle-class American family.

3. Experimentation across contexts-Learning collaboratives, both between diverse partners in one setting [54] and between international collaborators [55], can be a powerful innovation tool when combined with "disciplined experimentation [8]." Timely publication of both positive and negative findings that result is a must, and requires journals and their editors to prize such experiences.

4. Open access for open dialogue-When accessing a single journal article can cost an African physician in the public sector two days' salary (and what of the health journalist, or nurse?), even the best innovations will fail to make an impact. Open access journals are essential for harnessing the benefits of shared innovation.

5. Reciprocity and respect-International health research has long been semi-colonial and extractive [56]; global health equity also means intellectual partnership with the goal of equity. True partnership in international research projects means having local co-principal investigators and equal contributions to and representation on scientific articles. Further, not all "reverse innovations" stem from economic scarcity; scientists and program managers in poor

\section{Table 3 Supportive environment for context-specific health technology development}

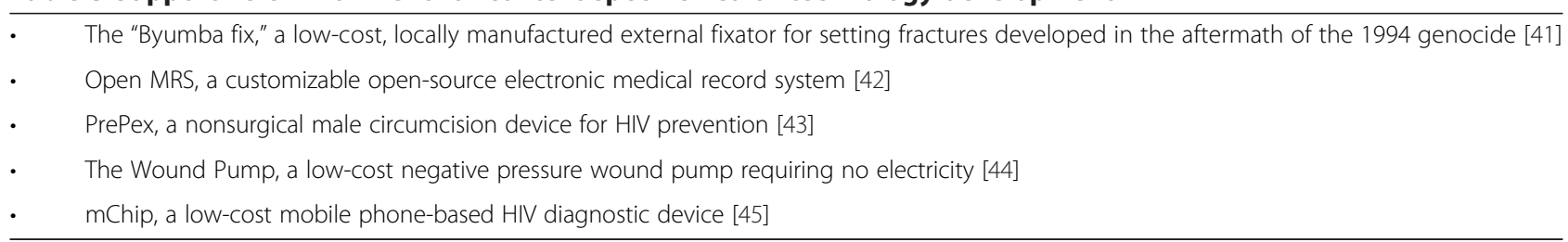


countries are endowed with creativity and cultural resources just like their rich-country counterparts, and partners on both sides have lessons to share.

Looking forward, we believe that linking humility and bold vision to scientific rigor is the surest route to value and equity in global health. Some of the leading challenges facing health systems around the world in the twenty-first century may not be amenable to innovations derived from other contexts, but many are: all countries face the task of providing universal access to high quality, high value care. For the still-nascent field of global health to advance, we must embrace two-way learning; after all, we live in one world, not three, and the communities where this journal's online readers live are as surely on the globe as are Kigali or Boston [57].

\section{Author details}

${ }^{1}$ Ministry of Health of Rwanda, Kigali, Rwanda. ${ }^{2}$ Harvard Medical School, Boston, MA, USA. ${ }^{3}$ Geisel School of Medicine at Dartmouth, Hanover, NH, USA. ${ }^{4}$ Dartmouth Center for Health Care Delivery Science, Hanover, NH, USA. ${ }^{5}$ Rwanda Biomedical Center, Kigali, Rwanda. ${ }^{6}$ Partners In Health, Boston, MA, USA. ${ }^{7}$ Brigham and Women's Hospital, Boston, MA, USA. ${ }^{8}$ MASS Design Group, Boston, MA, USA. ${ }^{9}$ Global Health Delivery Partnership, Boston, MA, USA. ${ }^{10}$ Massachusetts Institute of Technology, Boston, MA, USA.

Received: 1 June 2013 Accepted: 6 August 2013

Published: 30 August 2013

\section{References}

1. Marseille E, Hofmann PB, Kahn JG: HIV prevention before HAART in subSaharan Africa. Lancet 2002, 359:1851-1856.

2. Herbert B: In America, refusing to save Africans; 2001. www.nytimes.com/ 2001/06/11/opinion/in-america-refusing-to-save-africans.html.

3. UNAIDS: UNAIDS update: How Africa turned AIDS around. Geneva: Joint United Nations Program on HIV/AIDS; 2013. http://www.unaids.org/en/ media/unaids/contentassets/documents/document/2013/05/ 20130521_Update_Africa.pdf.

4. Cohen MS, Chen YQ, McCauley M, Gamble T, Hosseinipour MC, Kumarasamy N, et al: Prevention of HIV-1 infection with early antiretroviral therapy. N Engl J Med 2011, 365:493-505.

5. Mills EJ, Nachega JB, Buchnan I, Orbinski J, Attaran A, Singh S, et al: Adherence to antiretroviral therapy in sub-Saharan Africa and North America. JAMA 2006, 296:679-690.

6. Ortblad KF, Lozano R, Murray CJL: The burden of HIV: insights from the GBD 2010. AIDS 2013, 27:2003-2017.

7. Elul B, Basinga P, Nuwagaba-Biribonwoha H, Saito S, Horowitz D, Nash D, et al: High levels of adherence and viral suppression in a nationally representative sample of HIV-infected adults on antiretroviral therapy for 6, 12, and 18 months in Rwanda. PLOS ONE 2013, 8:e53586.

8. Govindarajan $V$, Trimble C: Partners In Health's radical model for care: developing world medicine can improve rich world health. In Reverse innovation: create far from home, win everywhere. Boston: Harvard Business Review Press; 2012.

9. Berwick DM: Lessons from developing nations on improving health care. BMJ 2004, 328:1124-1129.

10. Richards T, Tumwine J: Poor countries make the best teachers: it is not only what you spend on health, but how you spend it. BMJ 2004, 329:1113-1114.

11. Rabkin M, de Cock KM, El-Sadr WM: Lessons learned from Africa. J Acquir Immune Defic Syndr 2010, 55:S141-S143.

12. Syed SB, Dadwal V, Rutter P, Storr J, Hightower JD, Gooden R, et al: Developed-developing country partnerships: benefits to developed countries? Glob Heal 2012, 8:17.

13. Crisp N: Turning the world upside down: the search for global health in the 21st century. London: Royal Society of Medicine Press; 2010.
14. Salzburg Global Seminar: Innovating for value in health care delivery: better cross-border learning, smarter adaptation, and adoption; 2011. http://www. salzburgglobal.org/current/Sessions-b.cfm?IDSPECIAL_EVENT=2867.

15. Howitt P, Darzi A, Yang GZ, Ashrafian H, Atun R, Barlow J, et al: Technologies for global health. Lancet 2012, 380:507-535.

16. Simiyu K, Daar AS, Hughes M, Singer PA: Science-based health innovation in Rwanda: unlocking the potential of a late bloomer. BMC Int Health and Human Rights 2010, 10:S3.

17. Ministry of Health of Rwanda: Health sector research policy; 2012. http://www.moh. gov.rw/fileadmin/templates/Docs/Health-Sector-Research-Policy.pdf.

18. Logie DE, Rowson M, Ndagije F: Innovations in Rwanda's health system: looking to the future. Lancet 2008, 372:256-261.

19. Farmer PE, Nutt CT, Wagner CM, Sekabaraga C, Nuthulaganti T, Weigel JL, et al: Reduced premature mortality in Rwanda: lessons from success. BMJ 2013, 365:20-22.

20. Govindarajan V, Trimble C: The other side of innovation: solving the execution challenge. Boston: Harvard Business Review Press; 2010.

21. Sekabaraga C, Diop F, Soucat A: Can innovative health financing policies increase access to MDG-related services? Evidence from Rwanda. Health Policy Plan 2011, 26:ii52-ii62.

22. Lu C, Chin B, Lee J, Basinga P, Hirschhorn LR, Hill K, et al: Towards universal health coverage: an evaluation of Rwanda mutuelles in its first eight years. PLOS ONE 2012, 7:e39282.

23. Basinga P, Gertler PJ, Binagwaho A, Soucat ALB, Sturdy J, Vermeersch CMJ: Effect on maternal and child health services in Rwanda of payment to primary health-care providers for performance: an impact evaluation. Lancet 2011, 377:1421-1428.

24. de Walque D, Gertler PJ, Bautista-Arredondo S, Kwan A, Vermeersch C, Bizimana JDJ, et al: Using provider performance incentives to increase HIV testing and counseling services in Rwanda. World Bank Policy Res Working Paper 6364. http://www-wds.worldbank.org/servlet/ WDSContentServer/WDSP/IB/2013/02/19/000158349_20130219134453/ Rendered/PDF/wps6364.pdf.

25. Franke MF, Kaigamba F, Socci AR, Hakizamungu M, Patel A, Bagiruwigize E, et al: Improved retention associated with community-based accompaniment for antiretroviral therapy delivery in rural Rwanda. Clin Infect Dis 2013, 56:1319-1326.

26. Thomson DR, Rich ML, Kaigamba F, Socci AR, Hakizamungu M, Bagiruwigize E: Community-based accompaniment and psychosocial health outcomes in HIV-infected adults in Rwanda: a prospective study. AIDS Behav 2013. [e-pub ahead of print]. http://www.ncbi.nlm.nih.gov/ pubmed/23443977.

27. Drobac PC, Basinga P, Condo J, Farmer PE, Finnegan KE, Hamon J, et al: Comprehensive and integrated district health systems strengthening: the Rwanda Population Health Implementation and Training (PHIT) Partnership. BMC Health Serv Res 2013, 13:S5.

28. Price JE, Leslie JA, Welsh $M$, Binagwaho A: Integrating HIV clinical services into primary health care in Rwanda: a measure of quantitative effects. AIDS Care 2009, 21:608-614.

29. Shumbusho F, van Griensven J, Lowrance D, Turate I, Weaver MA, Price J, Binagwaho A: Task shifting for scale-up of HIV care: evaluation of nursecentered antiretroviral treatment at rural health centers in Rwanda. PLOS Medicine 2010, 6:e1000163.

30. Rich ML, Miller AC, Niyigena P, Franke MF, Niyonzima JB, Socci A, et al: Excellent clinical outcomes and high retention in care among adults in a community-based HIV treatment program in rural Rwanda. J Acquir Immune Defic Syndr 2012, 59:e35-e42.

31. Gasana M, Mucyo Y, Kamanzi E, Nutt CT, Wagner CM, Binagwaho A: High treatment success rates in Rwanda's national MDR-TB programme, 2005-2011. Int J Tubercul Lung Dis 2012, 16:S186.

32. Binagwaho A, Wagner CM, Gatera M, Karema C, Nutt CT, Ngabo F: Achieving high coverage in Rwanda's national human papillomavirus vaccination programme. Bull World Health Organ 2012, 90:623-628.

33. Makaka A, Breen S, Binagwaho A: Universal health coverage in Rwanda: a report of innovations to increase enrolment in community-based health insurance. Lancet 2013, 380:S7.

34. Nsanzimana S, Ruton H, Lowrance DH, Cishahayo S, Nyemazi JP, Muhayimpundu R, et al: Cell phone-based and internet-based monitoring and evaluation of the national antiretroviral treatment program during rapid scale-up in Rwanda: TRACnet, 2004-2010. J Acquir Immune Defic Syndr 2012, 59:e17-e23. 
35. Binagwaho A, Mugwaneza P, Irakoze AA, Nsanzimana S, Agbonyitor M, Nutt CT, et al: Scaling up early infant diagnosis of HIV in Rwanda, 2008-2010. J Public Health Policy 2013, 34:2-16.

36. Shakow ADA, Bukhman G, Adebona O, Greene J, Ngirabega JDJ, Binagwaho A: Transforming south-south technical support to fight non-communicable diseases. Global Health 2012, 7:35-45.

37. Anatole $M$, Magge $H$, Redditt $V$, Karamaga A, Niyonzima $S$, Drobac $P$, et al: Nurse mentorship to improve the quality of health care delivery in rural Rwanda. Nurs Outlook 2013, 61:137-144.

38. Karema C, Aregawi MW, Rukundo A, Kabayiza A, Mulindahabi M, Fall IS, et al: Trends in malaria cases, hospital admissions and deaths following scale-up of anti-malarial interventions, 2000-2010, Rwanda. Malar J 2012, 11:236.

39. Pevzner ES, Vandebriel G, Lowrance DW, Gasana M, Finlay A: Evaluation of the rapid scale-up of collaborative TB/HIV activities in TB facilities in Rwanda, 2005-2009. BMC Publ Health 2011, 11:550.

40. World Bank and International Finance Corporation: Doing business 2013: smarter regulations for small and medium-size enterprises. Washington DC: World Bank; 2013.

41. Farmer P: "Landmine boy" and stupid deaths. In Partner to the poor: a Paul Farmer reader. Berkeley: University of California Press; 2010.

42. Amoroso CL, Akimana B, Wise B, Fraser HS: Using electronic medical records for HIV care in rural Rwanda. Stud Health Technol Inform 2010, 160:337-341.

43. Mutabazi V, Kaplan SA, Rwamasirabo E, Bitega JP, Ngeruka LM, Savio D, et al: HIV prevention: male circumcision comparison between a nonsurgical device to a surgical technique in resource-limited settings: a prospective, randomized, nonmasked trial. J Acquir Immune Defic Syndr 2012, 61:49-55.

44. Zurovcik D, Slocum A, Mody G, Riviello R, Sheridan R: Development of simplified negative pressure wound therapy device for low-resource settings. In Presented at: global humanitarian technology conference 2011. Seattle: Institute of Electrical and Electronic Engineers; 2011. http:// ieeexplore.ieee.org/stamp/stamp.jsp?tp=\&arnumber=6103614.

45. Chin CD, Cheung YK, Laksanasopin T, Modena MM, Chin SY, Sridhara AA, et al: Mobile device for disease diagnosis and data tracking in resourcelimited settings. Clin Chem 2013, 59:629-640.

46. Kim JY, Farmer P, Porter ME: Redefining global health-care delivery. Lancet 2013. [e-pub ahead of print]. http://www.thelancet.com/journals/lancet/ article/PIIS0140-6736(13)61047-8/.

47. Novak S: Hands-on medical education in Rwanda; 2012. http://www.nytimes com/2012/05/14/world/africa/14iht-educlede14.html?pagewanted=all\&_r=0.

48. Cary J, Martin CE: Dignifying design. ; 2012. http://www.nytimes.com/2012/ 10/07/opinion/sunday/dignifying-design.html?pagewanted=all.

49. de Monchaux T: South-to-north thinking; 2013. http://www.metropolismag. com/February-2013/South-to-North-Thinking/.

50. Binagwaho A, Kyamanywa P, Farmer PE, Nuthulaganti T, Umubyeyi B, Nyemazi JP, et al: Redefining global health partnerships: Rwanda's human resources for health program. New Engl J Med. in press.

51. Drobac P, Basilico M, Messac L, Walton D, Farmer P: Building an effective rural health delivery model in Haiti and Rwanda. In Reimagining global health. Berkeley: University of California Press; 2013.

52. Farmer P, Rejouit JR: How we can stop cholera; 2010. http://www. thedailybeast.com/newsweek/2010/12/13/how-to-stop-cholera-in-haiti.html.

53. Kleinman A, Benson P: Anthropology in the clinic: the problem of cultural competency and how to fix it. PLOS Medicine 2006, 3:e294.

54. Lim Y, Kim JY, Rich M, Stulac S, Niyonzima JB, Smith-Fawzi MCS, et al Improving prevention of mother-to-child transmission of HIV care and related services in eastern Rwanda. PLOS Medicine 2010, 7:e1000302.

55. Bell P, Binagwaho A: The joint learning initiative on children and HIV/ AIDS. Lancet 2006, 368:1850-1851.

56. Costello A, Zumla A: Moving to research partnerships in developing countries. BMJ 2000, 321:827-829.

57. Farmer P, Kim JY, Kleinman A, Basilico M: Introduction: a biosocial approach. In Reimagining global health. Berkeley: University of California Press; 2013.

doi:10.1186/1744-8603-9-37

Cite this article as: Binagwaho et al:: Shared learning in an

interconnected world: innovations to advance global health equity.

Globalization and Health 2013 9:37.

\section{Submit your next manuscript to BioMed Central and take full advantage of:}

- Convenient online submission

- Thorough peer review

- No space constraints or color figure charges

- Immediate publication on acceptance

- Inclusion in PubMed, CAS, Scopus and Google Scholar

- Research which is freely available for redistribution 